\title{
Evaluation of The Effects of Desipramine, Venlafaxine And Bupropion on Depression and Anxiety in Mice By Forced Swimming Test and Elevated Plus Maze Test
}

\author{
Desipramin, Venlafaksin ve Bupropionun Farelerdeki
}

Depresyon ve Anksiyete Üzerine Etkilerinin Zorunlu Yüzme Testi ve Yükseltilmiş Artı Labirent Testi ile Değerlendirilmesi

\section{Mehmet Hanifi Tanyeri', Mehmet Emin Buyukokuroglu2, Pelin Tanyeri2*,} Oguz Mutlü3, Güner Ulak³, Füruzan Yildiz Akar³, Bekir Faruk Erden ${ }^{3}$

'Yenikent Government Hospital, Department of Urology, 54100 Sakarya/Turkey ${ }^{2}$ Sakarya University, Faculty of Medicine, Department of Pharmacology, 54100-Sakarya/Turkey ${ }^{3}$ Kocaeli University, Faculty of Medicine, Department of Pharmacology, 41380-Kocaeli/Turkey

Yazışma Adresi / Correspondence:

Pelin Tanyeri

Sakarya University Medical Faculty Department of Pharmacology 54100 Sakarya-Turkey T: +905305125590 E-mail: pelintanyeri@yahoo.com

Geliş Tarihi / Received : 15.11.2018 Kabul Tarihi / Accepted : 12.12.2018

\begin{abstract}
Aim This study aimed to investigate the effects of desipramine, venlafaxine and bupropion on depression and anxiety in mice. We used a classic tricyclic antidepressant, desipramine; a serotonin-norepinephrine reuptake inhibitor, venlafaxine; and a second-generation antidepressant agent that blocks the central reuptake of noradrenaline and dopamine, bupropion. ( Sakarya Med J 2018, 8(4):820-829 )

Material and Imipramine $(30 \mathrm{mg} / \mathrm{kg}$ ), desipramine $(7.5 \mathrm{mg} / \mathrm{kg}$ and $15 \mathrm{mg} / \mathrm{kg}$ ), venlafaxine $(4 \mathrm{mg} / \mathrm{kg}$ and $8 \mathrm{mg} / \mathrm{kg}$ ), and bupropion (20 mg/kg and 40

Methods $\mathrm{mg} / \mathrm{kg}$ ) significantly reduced immobility time in the FST compared to vehicle in a dose-dependent manner. Additionally, bupropion (40 mg/ $\mathrm{kg}$ ) was significantly more effective than imipramine.

Results Diazepam ( $2 \mathrm{mg} / \mathrm{kg}$ ), desipramine $(7.5 \mathrm{mg} / \mathrm{kg}$ and $15 \mathrm{mg} / \mathrm{kg})$, venlafaxine ( $4 \mathrm{mg} / \mathrm{kg}$ and $8 \mathrm{mg} / \mathrm{kg}$ ), and bupropion $(20 \mathrm{mg} / \mathrm{kg}$ and $40 \mathrm{mg} /$ $\mathrm{kg})$ significantly increased the time spent in the open arms of the EPM compared to vehicle in a dose-dependent manner. Diazepam $(2 \mathrm{mg} /$ $\mathrm{kg})$, desipramine $(7.5 \mathrm{mg} / \mathrm{kg}$ and $15 \mathrm{mg} / \mathrm{kg})$, venlafaxine $(8 \mathrm{mg} / \mathrm{kg})$ and bupropion $(20 \mathrm{mg} / \mathrm{kg}$ and $40 \mathrm{mg} / \mathrm{kg})$ significantly increased the number of entries into the open arms compared to the vehicle-treated group. Additionally, bupropion $(40 \mathrm{mg} / \mathrm{kg})$ was significantly more effective than diazepam.

Conclusion Desipramine, venlafaxine and bupropion $(20 \mathrm{mg} / \mathrm{kg})$ exerted significant antidepressant-like effects that were not significantly different than the effects of imipramine. Additionally, bupropion $(40 \mathrm{mg} / \mathrm{kg})$ exerted significant antidepressant-like effects and was more effective than imipramine. Similarly, desipramine, venlafaxine and bupropion $(20 \mathrm{mg} / \mathrm{kg})$ exerted significant anxiolytic-like effects that were not significantly different than the effects of diazepam. Additionally, bupropion $(40 \mathrm{mg} / \mathrm{kg})$ exerted significant anxiolytic-like effects and was more effective than diazepam.

Keywords desipramine; venlafaxine; bupropion; depression; anxiety
\end{abstract}

Öz

Amaç Bu çalışmada, farelerde desipramin, venlafaksin ve bupropiyonun depresyon ve anksiyete üzerine etkilerini araştırmayı amaçladık. ( Sakarya Tip Dergisi 2018, 8(4):820-829).

Gereç ve Klasik trisiklik antidepresan, desipramin, serotonin-norepinefrin geri alım inhibitörü venlafaksin ve ikinci jenerasyon antidepresan bir ajan

Yöntem olan noradrenalin ve dopamin gerialım inhibitörü bupropionun farelerde zorunlu yüzme testi (FST) ve yükseltilmis artı labirent testi (EPM) üzerindeki etkilerini araştırmayı amaçladık.

Bulgular Imipramin ( $30 \mathrm{mg} / \mathrm{kg})$, desipramin $(7,5 \mathrm{mg} / \mathrm{kg}$ ve $15 \mathrm{mg} / \mathrm{kg})$, venlafaksin $(4 \mathrm{mg} / \mathrm{kg}$ ve $8 \mathrm{mg} / \mathrm{kg})$ ve bupropion $(20 \mathrm{mg} / \mathrm{kg}$ ve $40 \mathrm{mg} /$ $\mathrm{kg}$ ) FST'de hareketsizlik zamanını önemli ölçüde doza bağlı bir şekilde azalttı. Ayrıca bupropion $(40 \mathrm{mg} / \mathrm{kg})$ da imipramine göre anlamlı derecede etkiliydi.

Diazepam (2 mg/kg), desipramin ( $7.5 \mathrm{mg} / \mathrm{kg}$ ve $15 \mathrm{mg} / \mathrm{kg}$ ), venlafaksin $(4 \mathrm{mg} / \mathrm{kg}$ ve $8 \mathrm{mg} / \mathrm{kg}$ ) ve bupropion $(20 \mathrm{mg} / \mathrm{kg}$ ve $40 \mathrm{mg} / \mathrm{kg})$ EPM'de açk kollarda kalıs süresini önemli ölc̈üde doza bağlırtırdı. Diazepam $(2 \mathrm{mg} / \mathrm{kg})$, desipramin $(7,5 \mathrm{mg} / \mathrm{kg}$ ve $15 \mathrm{mg} / \mathrm{kg})$ venlafak$\sin (8 \mathrm{mg} / \mathrm{kg})$ ve bupropion $(20 \mathrm{mg} / \mathrm{kg}$ ve $40 \mathrm{mg} / \mathrm{kg})$ açık kola giriș sayısını da artırdı. Ayrıca bupropion $(40 \mathrm{mg} / \mathrm{kg})$ diazepamdan anlamlı derecede daha etkiliydi.

Sonuç Desipramin, venlafaksin ve bupropion $(20 \mathrm{mg} / \mathrm{kg})$, imipraminin etkilerinden önemli ölçüde farklı olmayan antidepresan benzeri etkilere neden olmuştur. Bunun yanında bupropion $(40 \mathrm{mg} / \mathrm{kg}$ ) antidepresan benzeri etki göstermiştir ve bu etkiler imipraminden daha güçü̈dür. Benzer şekilde, desipramin, venlafaksin ve bupropion $(20 \mathrm{mg} / \mathrm{kg}$ ), diazepamın etkilerinden önemli ölçüde farklı olmayan anlamlı anksiyolitik benzeri etkiler göstermişlerdir. Ayrıca bupropion $(40 \mathrm{mg} / \mathrm{kg}$ ) anlamlı anksiyolitik benzeri etkiler göstermiş ve bu etkiler diazepamdan daha güçlüdür. 


\section{Introduction}

Depression is the second most common chronic disease, and its global presence has expanded widely. It is estimated that about half of the patients suffering from depression are unaware of their disease or are misdiagnosed. ${ }^{1}$ Anxiety is also a complicated behavior in humans and animals that may lead to a wide range of problems in the central nervous system (CNS). Depression and anxiety disorders are burdensome conditions with lifetime prevalence rates of approximately 7-20\% and 11-27\% respectively., ${ }^{2,3}$ It has also been reported that anxiety affects one-eighth of the population and, in severe forms, has debilitating effects on quality of life. ${ }^{4}$ Sexual problems are more common among patients with depression and anxiety disorders than among the general population. ${ }^{5,6}$

Depression is a neurochemical disorder arising from the hypofunctioning of brain mono-amine systems, including the serotonergic, noradrenergic, and/or dopaminergic pathways. ${ }^{7}$ Additionally, different studies have suggested the role of dopamine in the pathogenesis of depression. ${ }^{8}$ Animal research has shown that the second-generation antidepressant bupropion increases monoaminergic neurotransmission differently than other antidepressants. ${ }^{9}$ Bupropion inhibits the reuptake of noradrenaline and dopamine but has no significant serotonergic effects. ${ }^{10}$ Animal studies have shown that bupropion has no presynaptic or postsynaptic effect on serotonergic neurotransmission. ${ }^{11,12}$ Dopaminergic agonists facilitate sexual behavior. ${ }^{13}$ Thus, bupropion has a positive effect on sexual desire. ${ }^{14}$

The main objective of our study was to compare the antidepressant and anxiolytic-like effects of widely prescribed classes of antidepressants: desipramine, venlafaxine and bupropion. Thus, we investigated the acute effects of these drugs using the forced swimming and elevated plus maze tests in mice. A well-known antidepressant, imipramine, and a well-known anxiolytic, diazepam, were used as positive controls.

\section{Materials and methods}

\section{Animals}

Male inbred BALB/c ByJ mice (Animal Research Center, Bursa-Turkey) aged 7 weeks upon arrival to the laboratory were used in this study. Animals (4-5 per cage) were kept in the laboratory at $21 \pm 1.5{ }^{\circ} \mathrm{C}$ with $60 \%$ relative humidity under a $12 \mathrm{~h}$ light/dark cycle (light on at 8.00 p.m.) for 2 weeks before experimentation. Tap water and food pellets were available ad libitum. All procedures involving animals were in compliance with the European Community Council Directive of 24 November 1986, and ethical approval was granted by the Kocaeli University Ethics Committee (Number: AEK 7/6, Kocaeli, Turkey).

\section{Drugs}

Imipramine, diazepam, desipramine, venlafaxine and bupropion were purchased from Sigma Chemicals (St Louis, Mo, USA). All drugs were dissolved in 0.9\% physiological saline. Saline was used as the vehicle in control experiments. Venlafaxine was given subcutaneously (s.c.), and the other drugs were given intraperitoneally (i.p.) in a volume of $0.1 \mathrm{ml}$ per $10 \mathrm{~g}$ body weight of mice. All doses used were chosen based on previous behavioral studies. ${ }^{15-18}$ Drugs were freshly prepared on the day of the experiment. 


\section{Experimental Design}

The mice were randomly divided into experimental groups as follows: saline; imipramine, $30 \mathrm{mg} /$ kg; desipramine, $7.5 \mathrm{mg} / \mathrm{kg}$; desipramine, $15 \mathrm{mg} / \mathrm{kg}$; venlafaxine, $4 \mathrm{mg} / \mathrm{kg}$; venlafaxine, $8 \mathrm{mg} /$ $\mathrm{kg}$; bupropion, $20 \mathrm{mg} / \mathrm{kg}$; and bupropion, $40 \mathrm{mg} / \mathrm{kg}$. Each experimental group consisted of 8-9 mice. All the experiments were performed between 10:00 a.m. and 12:00 p.m. Saline (vehicle), imipramine (30 mg/kg), desipramine ( $7.5 \mathrm{mg} / \mathrm{kg}$ and $15 \mathrm{mg} / \mathrm{kg}$ ), venlafaxine $(4 \mathrm{mg} / \mathrm{kg}$ and $8 \mathrm{mg} /$ $\mathrm{kg}$ ), and bupropion ( $20 \mathrm{mg} / \mathrm{kg}$ and $40 \mathrm{mg} / \mathrm{kg}$ ) were given 30 min before the forced swimming test and elevated plus maze test.

\section{Forced swimming test}

The FST, the most widely used behavioral test for the screening of antidepressant drugs, was performed as described by Porsolt et al..$^{19,20}$ Briefly, the mice were dropped individually into Plexiglas cylinders (height $25 \mathrm{~cm}$, diameter $10 \mathrm{~cm}$ ) containing $10 \mathrm{~cm}$ of water maintained at $23-25^{\circ} \mathrm{C}$ and left there for 6 min. The duration of immobility was recorded during the last 4 min of the 6 -min testing period. The absence of hind leg movement was recorded as immobility by stopwatch by a single observer who was aware of the treatment groups.

\section{Elevated Plus Maze Test}

Anxiety-related behavior was measured with the elevated plus maze test. The experiments were conducted in a dimly lit, semi-soundproof room, illuminated with a table lamp (80 lux). The maze was made of wood and consisted of two open $(29 \mathrm{~cm}$ long $\times 5 \mathrm{~cm}$ wide) and closed arms $(29 \mathrm{~cm}$ $\times 5 \mathrm{~cm}$ with $15 \mathrm{~cm}$ high walls) forming a square cross with a $5 \mathrm{~cm}$ square center piece. To avoid falls, the open arms were surrounded by a short $(1 \mathrm{~cm})$ plexiglass edge. The maze was elevated $40 \mathrm{~cm}$ above the floor. The open arms and central platform were painted white and enclosed arms were painted black.

Each mouse was placed at the center of the maze facing one of the open arms and allowed to explore the maze. During a 5-min test period, the number of entries into both open and enclosed arms of the maze (defined as the entry of all four limbs into the arms) and the time spent in the open arms was recorded. The observer was always located in the same position near the open arms and behind the animals. The open-arm activity was evaluated as the following: 1) time spent in the open arms relative to the total time spent in the plus maze (300 s), expressed as a percentage, and 2) number of entries into the open arms relative to the total number of entries into both the open and closed arms, expressed as a percentage. These values were used as indices of anxiety in mice. Any animal that fell off the maze was excluded from the experiment.

If the change in one of the parameters was statistically significant, then an effect on anxiety was considered to have occurred. The time spent in the open arms and the numbers of open arm entries were always observed to change in the same direction (i.e., both the time spent in the open arms and the number of open arm entries increased or both decreased).

\section{Open field test}

Since compounds altering motor activity may give false positive/negative effects in the elevated plus maze test, spontaneous locomotor activity of mice was evaluated by monitoring the activity of the animals in an open field $(33 \times 33 \times 30 \mathrm{~cm}$ square box). The animals were placed in the center
Sakarya Med ]

2018;8(4):820-829

TANYERi et al. Evaluation of The Effects of Antidepressants On Anxiety and Depression 
of the apparatus, and behaviors were recorded for a period of 5 min using the Etovision-XT video tracking system (Noldus, Netherlands). The locomotor activity was evaluated by measuring the total distance travelled in the apparatus and the speed of the animals.

\section{Statistics}

In evaluating the effects of individual groups, a one analysis of variance (ANOVA) post hoc Tukey test was performed. Data are expressed as the mean \pm S.E.M. P $<0.05$ was considered as statistically significant.

\section{Results}

\section{Forced swimming test}

One-way ANOVA showed a significant effect of imipramine, desipramine, venlafaxine and bupropion treatment on immobility time in the FST $[F(7,67)=70.919, p<0.0001]$. Imipramine $(30 \mathrm{mg} /$ $\mathrm{kg}$ ), desipramine $(7.5 \mathrm{mg} / \mathrm{kg}$ and $15 \mathrm{mg} / \mathrm{kg}$ ), venlafaxine $(4 \mathrm{mg} / \mathrm{kg}$ and $8 \mathrm{mg} / \mathrm{kg}$ ) and bupropion $(20 \mathrm{mg} / \mathrm{kg}$ and $40 \mathrm{mg} / \mathrm{kg}$ ) significantly reduced immobility time compared to the vehicle-treated group ( $p<0.001, p<0.01, p<0.001, p<0.01, p<0.001, p<0.001, p<0.001$, respectively, by Tukey test, Fig. 1).

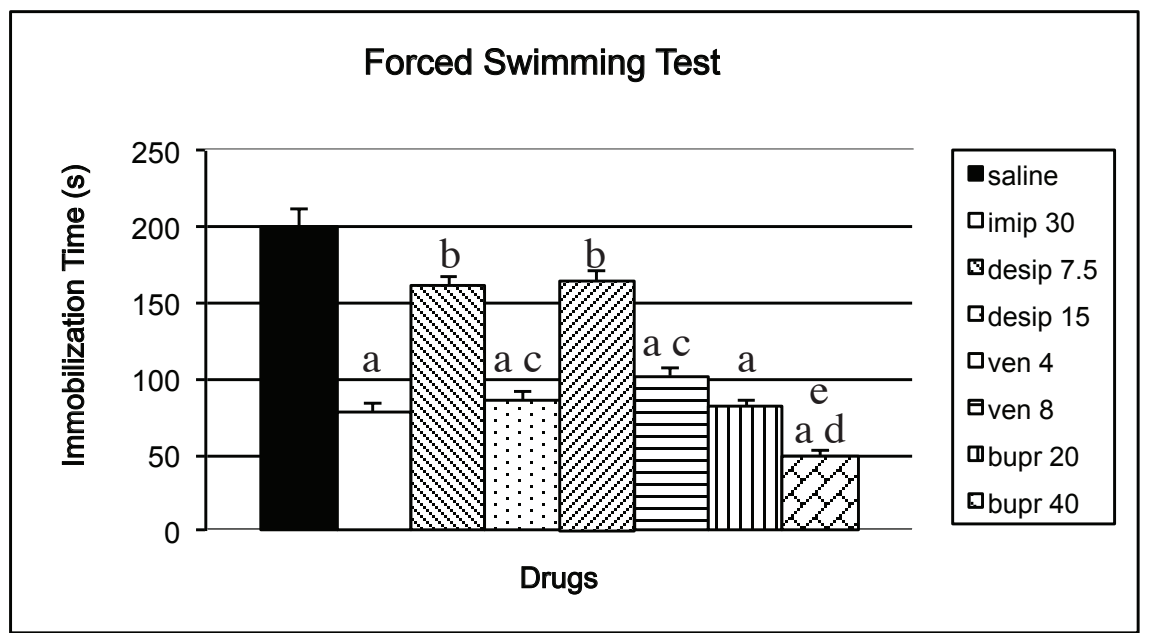

Figure 1. Effects of diazepam (diaze) $(2 \mathrm{mg} / \mathrm{kg}$ ), desipramine (desip) $(7.5 \mathrm{and} 15 \mathrm{mg} / \mathrm{kg})$, venlafaxine (ven) (4 and $8 \mathrm{mg} / \mathrm{kg}$ ) and bupropion (bupr) $(20$ and $40 \mathrm{mg} / \mathrm{kg}$ ) on immobility time in mice FST. Each column represents the mean \pm S.E.M. of 8-10 animals.

a $p<0.001, b p<0.01$ compared to vehicle control

c $p<0.001$ desipramine $(7.5 \mathrm{mg} / \mathrm{kg})$ compared to desipramine $(15 \mathrm{mg} / \mathrm{kg})$ and venlafaxine $(4 \mathrm{mg} /$ $\mathrm{kg})$ compared to venlafaxine $(8 \mathrm{mg} / \mathrm{kg})$

$\mathrm{d} p<0.01$ bupropion $(20 \mathrm{mg} / \mathrm{kg}$ ) compared to bupropion $(40 \mathrm{mg} / \mathrm{kg})$

e $p<0.01$ bupropion $(40 \mathrm{mg} / \mathrm{kg})$ compared to imipramine $(30 \mathrm{mg} / \mathrm{kg})$

One-way ANOVA revealed a significant effect of drug dose on the immobility time in the forced swimming test in all groups: desipramine $(7.5 \mathrm{mg} / \mathrm{kg})$ versus desipramine $(15 \mathrm{mg} / \mathrm{kg})$, venlafaxine (4 mg/kg) versus venlafaxine ( $8 \mathrm{mg} / \mathrm{kg}$ ), bupropion $(20 \mathrm{mg} / \mathrm{kg}$ ) versus bupropion $(40 \mathrm{mg} / \mathrm{kg})$ $(p<0.001, p<0.001, p<0.01$, respectively, Fig. 1$)$. Additionally, there was a significant difference in the immobility time between the imipramine $(30 \mathrm{mg} / \mathrm{kg})$ and bupropion $(40 \mathrm{mg} / \mathrm{kg})$ groups $(p<0.05)$. 


\section{Elevated plus maze test}

One-way ANOVA showed a significant effect of drug treatment on the time spent in the open arms in the EPM test $[F(7,64)=42.911, \rho<0.0001$, Fig. $2 A]$. Post-hoc comparisons revealed that diazepam (2 mg/kg), desipramine ( $7.5 \mathrm{mg} / \mathrm{kg}$ and $15 \mathrm{mg} / \mathrm{kg}$ ), venlafaxine $(4 \mathrm{mg} / \mathrm{kg}$ and $8 \mathrm{mg} / \mathrm{kg}$ ) and bupropion $(20 \mathrm{mg} / \mathrm{kg}$ and $40 \mathrm{mg} / \mathrm{kg}$ ) significantly increased the time spent in the open arms compared to the vehicle-treated group ( $p<0.001$, Fig $2 A$ ). One-way ANOVA revealed a significant effect of drug dose on the time spent in the open arms in all groups: desipramine $(7.5 \mathrm{mg} / \mathrm{kg})$ versus desipramine (15 mg/kg), venlafaxine (4 mg/kg) versus venlafaxine ( $8 \mathrm{mg} / \mathrm{kg}$ ), and bupropion $(20 \mathrm{mg} / \mathrm{kg})$ versus bupropion $(40 \mathrm{mg} / \mathrm{kg})(p<0.05, p<0.05, p<0.05$, respectively, Fig $2 A)$. Additionally, there was a significant difference in time spent in the open arms between the imipramine $(30 \mathrm{mg} / \mathrm{kg})$ and bupropion $(40 \mathrm{mg} / \mathrm{kg})$ groups $(p<0.01)$.

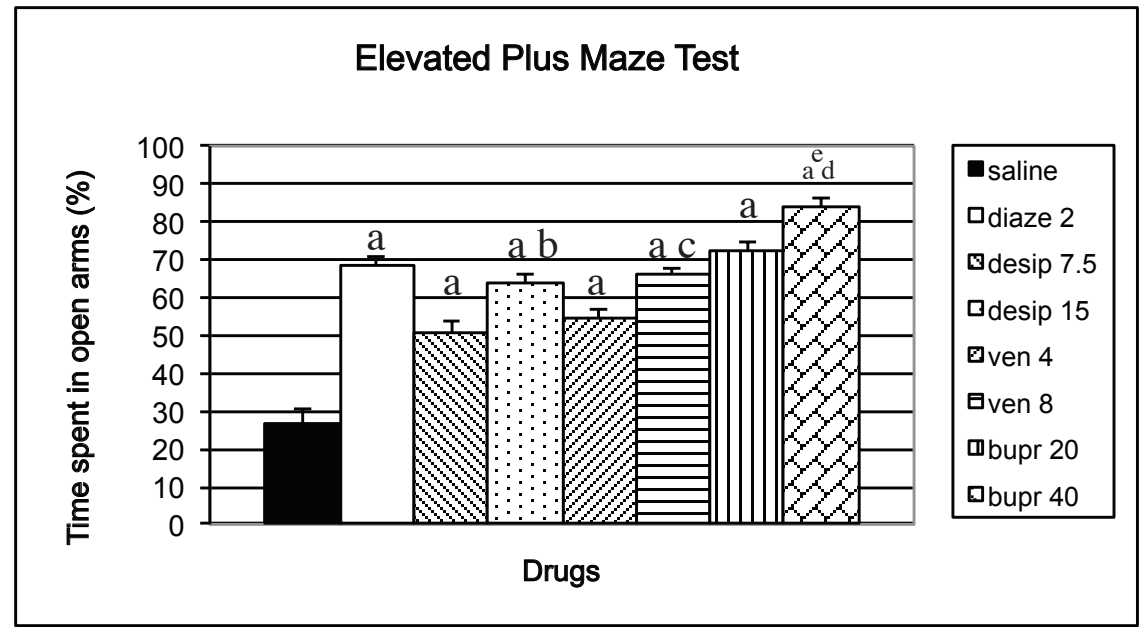

Figure 2A. Effects of diazepam (diaze)(2 mg/kg), desipramine(desip) $(7.5$ and $15 \mathrm{mg} / \mathrm{kg})$, venlafaxine (ven) (4 and $8 \mathrm{mg} / \mathrm{kg}$ ) and bupropion (bupr) (20 and $40 \mathrm{mg} / \mathrm{kg}$ ) on the \% time spent in open arms in mice EPM test. Each column represents the mean \pm S.E.M. of 8-9 animals.

a $p<0.001$ compared to vehicle control

b $p<0.05$ desipramine $(7.5 \mathrm{mg} / \mathrm{kg}$ ) compared to desipramine $(15 \mathrm{mg} / \mathrm{kg})$, venlafaxine $(4 \mathrm{mg} / \mathrm{kg})$ compared to venlafaxine $(8 \mathrm{mg} / \mathrm{kg}$ ) and bupropion $(20 \mathrm{mg} / \mathrm{kg}$ ) compared to bupropion $(40 \mathrm{mg} / \mathrm{kg}$ ) c $p<0.01$ bupropion $(40 \mathrm{mg} / \mathrm{kg})$ compared to diazepam $(2 \mathrm{mg} / \mathrm{kg})$

One-way ANOVA showed a significant effect of drug treatment on the number of entries into the open arms in the EPM test $[F(7,64)=10.835, p<0.0001$; Fig. $2 B]$. Post hoc comparisons revealed that diazepam ( $2 \mathrm{mg} / \mathrm{kg}$ ), desipramine $(7.5 \mathrm{mg} / \mathrm{kg}$ and $15 \mathrm{mg} / \mathrm{kg})$, venlafaxine $(8 \mathrm{mg} / \mathrm{kg}$ ) and bupropion $(20 \mathrm{mg} / \mathrm{kg}$ and $40 \mathrm{mg} / \mathrm{kg}$ ) significantly increased the number of entries into the open arms compared to the vehicle-treated group $(\rho<0.001, p<0.05, \rho<0.001, \rho<0.001, \rho<0.001, \rho<0.001$, respectively, Fig. 2B).

\section{Effects of drugs on locomotor activity in the open field test}

It is well known that an antidepressant-like effect in the FST and an anxiolytic-like effect in the EPM test can also be evoked by drugs which induce hyperactivity or hypoactivity. ${ }^{21}$ Thus, the influence of all of the above treatments on locomotor activity was concurrently evaluated. None of the drugs modified the total distance travelled $[F(8,75)=1.187$; Fig. 3] in the open field test.
Sakarya Med J

TANYERi et al. Evaluation of The Effects of Antidepressants On Anxiety and Depression 


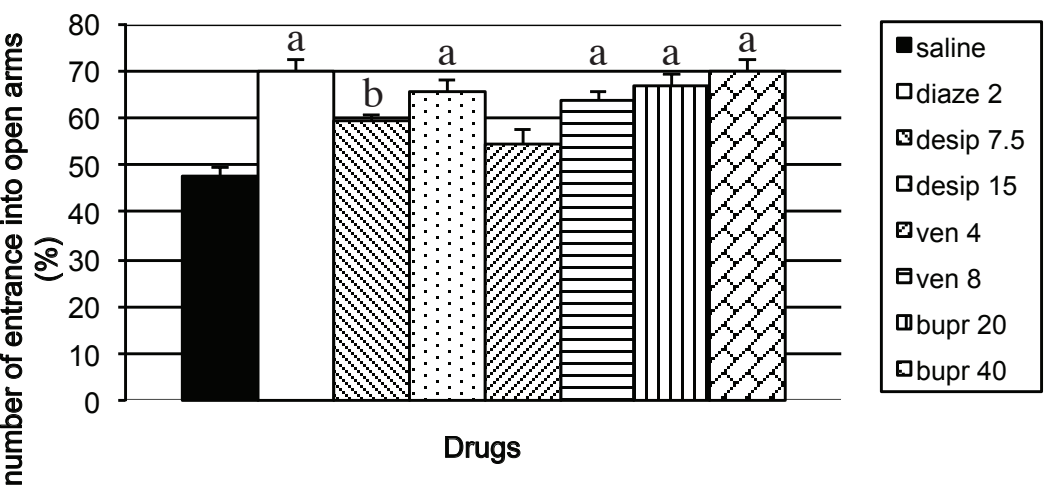

Figure 2B. Effects of diazepam (diaze) $(2 \mathrm{mg} / \mathrm{kg})$, desipramine(desip) $(7.5$ and $15 \mathrm{mg} / \mathrm{kg})$, venlafaxine (ven) (4 and $8 \mathrm{mg} / \mathrm{kg}$ ) and bupropion (bupr) $(20$ and $40 \mathrm{mg} / \mathrm{kg}$ ) on the \%number of entries to the open arms in mice EPM test. Each column represents the mean \pm S.E.M.of 8-9 animals. ap $<0.001$ compared to vehicle control $\mathrm{bp}<0.05$ compared to vehicle control

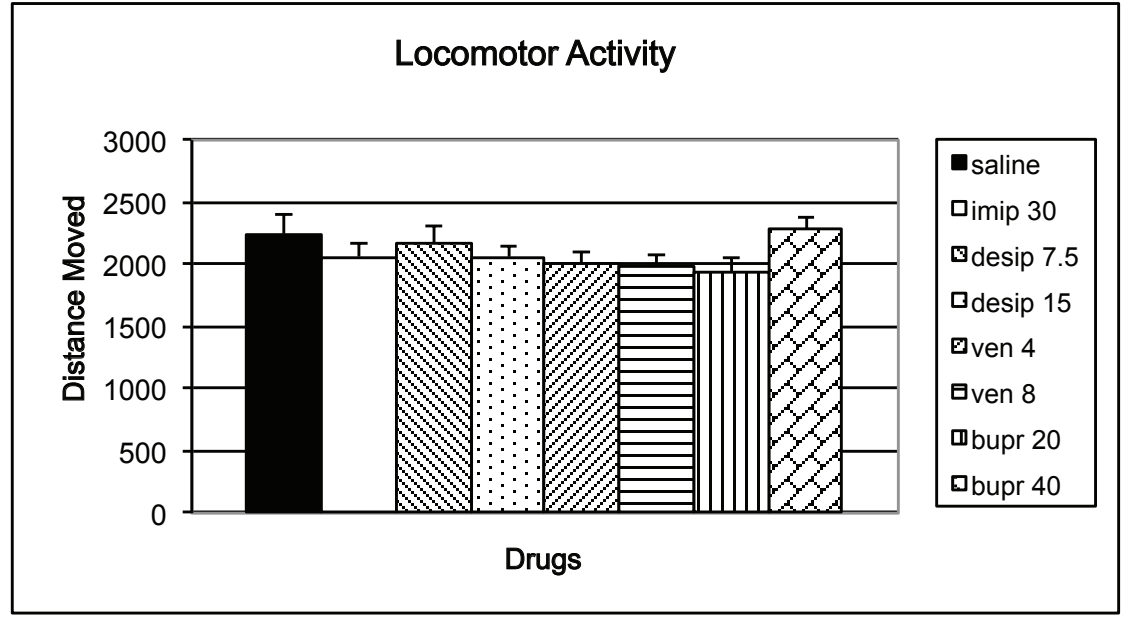

Figure 3. Effects of diazepam (diaze) $(2 \mathrm{mg} / \mathrm{kg}$ ), desipramine (desip) $(7.5$ and $15 \mathrm{mg} / \mathrm{kg}$ ), venlafaxine (ven) (4 and $8 \mathrm{mg} / \mathrm{kg}$ ) and bupropion (bupr) (20 and $40 \mathrm{mg} / \mathrm{kg}$ ) on total distance moved in the open field test. Each column represents the mean \pm S.E.M.of 8-10 animals. $p>0.05$ compared to vehicle control

\section{Discussion}

In the FST, the most widely used behavioral test for the screening of antidepressant drugs, the absence of hind leg movement was recorded as immobility. In our study, treatment with imipramine $(30 \mathrm{mg} / \mathrm{kg})$ and desipramine $(7,5$ and $15 \mathrm{mg} / \mathrm{kg})$ dose-dependently reduced the immobility time compared with saline, as was shown in recent studies. ${ }^{22-28}$ Again, we showed that venlafaxine $(4 \mathrm{mg} / \mathrm{kg}$ and $8 \mathrm{mg} / \mathrm{kg}$ ) reduced the immobility time in a dose-dependent manner in the FST. A similar result was shown in a previous study.29 Additionally, we found that bupropion ( $20 \mathrm{mg} /$ $\mathrm{kg}$ ) was as effective as imipramine in exerting significant antidepressant-like effects in the FST. Additionally, bupropion $(40 \mathrm{mg} / \mathrm{kg}$ ) was more effective than imipramine in exerting significant 
antidepressant-like effects in mice in the FST. In a previous study, bupropion significantly reduced the immobility time, similar to our results. $3^{0}$ Thus, bupropion has been proved to be an effective antidepressant drug.

In the elevated plus maze test, which is one of the most important tests for evaluating anxiety, the animals normally do not prefer the open arms. They prefer to stay in the enclosed arms, in which they appear to feel more confident. Thus, drugs that increase the time spent in the open arms are considered to be anxiolytic. Diazepam (2 mg/kg), desipramine $(7.5 \mathrm{mg} / \mathrm{kg}$ and $15 \mathrm{mg} / \mathrm{kg}$ ), venlafaxine (4 mg/kg and $8 \mathrm{mg} / \mathrm{kg}$ ) and bupropion $(20 \mathrm{mg} / \mathrm{kg}$ and $40 \mathrm{mg} / \mathrm{kg}$ ) significantly increased the time spent in the open arms compared to the vehicle-treated group. One-way ANOVA revealed significant differences between the groups (desipramine $(7.5 \mathrm{mg} / \mathrm{kg}$ ) versus desipramine (15 mg/kg), venlafaxine $(4 \mathrm{mg} / \mathrm{kg})$ versus venlafaxine $(8 \mathrm{mg} / \mathrm{kg})$, bupropion $(20 \mathrm{mg} / \mathrm{kg})$ versus bupropion (40 mg/kg) and imipramine (30 mg/kg) versus bupropion $(40 \mathrm{mg} / \mathrm{kg}$ ) in the time spent in the open arms. Diazepam ( $2 \mathrm{mg} / \mathrm{kg}$ ), desipramine $(7.5 \mathrm{mg} / \mathrm{kg}$ and $15 \mathrm{mg} / \mathrm{kg}$ ), venlafaxine (8 $\mathrm{mg} / \mathrm{kg}$ ) and bupropion $(20 \mathrm{mg} / \mathrm{kg}$ and $40 \mathrm{mg} / \mathrm{kg}$ ) significantly increased the number of entries into the open arms compared to the vehicle-treated group.

There is extensive comorbidity between depression and anxiety disorders. Anxiety, the emotional response to stress, is a key element of depression as well as the defining feature of anxiety disorders, and many antidepressants appear to be effective in the treatment of anxiety disorders as well as depression. Therefore, the pharmacological actions of these drugs must account for their efficacy in both. Brain noradrenergic, serotonergic and dopaminergic systems regulate or modulate many of the same behavioral dimensions that are affected in depression and anxiety disorders. Whereas much recent research has focused on the regulatory effects of antidepressants on synaptic function and cellular proteins, less emphasis has been placed on monoaminergic regulation at a more global systemic level, or how such systemic alterations in monoaminergic function might alleviate the behavioral, cognitive, emotional and physiological manifestations of depression and anxiety disorders. ${ }^{31}$

The monoamine hypothesis of depression states that depression is caused by a functional deficit of monoamines (norepinephrine, serotonin and dopamine) at certain sites in the brain. ${ }^{32}$ Studies show that the dopaminergic system, in part, may also be implicated in the regulation of mood. ${ }^{33}$ Currently, there is evidence from several reports regarding the efficacy of antidepressants related to the potentiation of dopaminergic neurotransmission in the treatment of depression. ${ }^{33,34}$ Several studies have also implicated dopamine receptors in depression and anxiety and in the mechanistic action of antidepressants. ${ }^{35-37}$ Furthermore, dopaminergic mechanisms may be involved in the regulation of male sexual behavior. ${ }^{38}$ Depressive symptoms have been shown to be related to sexual dysfunction in the general population. ${ }^{39}$ Additionally, depressive symptoms are thought to be associated with decreased sexual arousability. ${ }^{40}$ On the other hand, sexual dysfunction is associated with anxiety and depression. While bupropion inhibits the reuptake of both noradrenaline and dopamine, it has no effects on serotonin, histamine, acetylcholine or adrenaline receptors. ${ }^{41}$ Controlled trials have shown that bupropion improves overall sexual dysfunction. In addition, some uncontrolled studies revealed that bupropion has been effective in treating sexual dysfunction caused by other antidepressants. ${ }^{42-46}$
Sakarya Med ]

TANYERi et al. Evaluation of The Effects of Antidepressants On Anxiety and Depression 
In our study, desipramine, venlafaxine and bupropion $(20 \mathrm{mg} / \mathrm{kg}$ ) were as effective as imipramine in exerting significant antidepressant-like effects on mice in the FST. Additionally, bupropion (40 $\mathrm{mg} / \mathrm{kg}$ ) was more effective than imipramine in exerting significant antidepressant-like effects on mice in the FST. Similarly, desipramine, venlafaxine and bupropion $(20 \mathrm{mg} / \mathrm{kg})$ were as effective as diazepam in exerting significant anxiolytic-like effects on mice in the EPM test. Additionally, bupropion $(40 \mathrm{mg} / \mathrm{kg}$ ) was more effective than diazepam in exerting significant anxiolytic-like effects on mice in the EPM test. All three drugs were effective at altering depression- and anxiety-like behavior in our study, but bupropion had a superior antidepressant and anxiolytic effect compared to other antidepressants.

Desipramine and venlafaxine, but especially bupropion, seem to be good choices for antidepressant and anxiolytic agents due to their effectiveness in treating depression and anxiety associated with erectile dysfunction patients. Further studies, including cellular and molecular studies, are needed to support our results. 
1. Sharp LK, Lipsky MS. Screening for depression across the lifespan: a review of measures for use in primary care settings. Am Fam Physician 2002;66(6):1001-8.

2. Hirschfeld R, Weisssman M (2002). Risk factors for major depression and bipolar disorder. In: Davis K, Charney D Coyle J, Nemeroff C (eds). Neuropsychopharmacology The Fifth Generation of Progress. Lippincott Williams \& Wilkins: Philadelphia pp 1018-1025.

3. Merikangas K, Pine D (2002). Genetic and other vulne rability factors for anxiety and stress disorders. In: Davis K, Charney D, Coyle J, Nemeroff C (eds). Neuropsychopharmacology: The Fifth Generation of Progress. Lippincott Williams \& Wilkins: Philadelphia pp 868-882.

4. Thakur P, Rana AC. Effect of cissampelos pareira leaves on anxiety-like behavior in experimental animals. J Tradit Complement Med 2013;3(3):188-93.

5. Araujo AB, Durante R, Feldman HA, Goldstein I, McKinlay JB. (1998) The relationship between depressive symptoms and male erectile dysfunction: cross-sectional results from the Massachusetts Male Aging Study. Psychosom Med60: 458-465.

6. Hale VE, Strassberg DS (1990) The role of anxiety on sexual arousal. Arch Sex Behav19: 569-581.

7. Hirschfeld RMA. History and evolution of the monoamine hypothesis of depression. J Clin Psychiatry 2000;61(suppl 6):4-6.

8. Brown AS, Gershon S (1993) Dopamine and depression. J Neural Transm Gen Sect 91 (23):75-109

9. Paterson NE, Markou A. Animal models and treatments for addiction and depression co-morbidity. Neurotox Res. 2007 Jan; 11(1):1-32

10. Wilens TE, Haight BR, Horrigan JP et al. Bupropion XL in adults with attention-deficit/hyperactivity disorder: a randomized, placebo-controlled study. Biol Psychiatry 2005 57: 793-801

11. Ferris RM, Cooper BR. Mechanism of antidepressant activity of bupropion. J Clin Psychiatry Monograph 1993;11(1):2-14.

12. Ascher JA, Cole JO, and Colin J-N. et al. Bupropion: a review of its mechanism of antidepressant activity. J Clin Psychiatry 1995 56:395-401.

13. Hull EM, Dominguez JM. Sexual behavior in male rodents. Horm Behav. 2007 Jun;52(1):45-55

14. Segraves RT, Clayton A, Croft $\mathrm{H}$ et al. Bupropion sustained release for the treatment of hipoactive sexual desire disorder in premenopausal women. J Clin Psychopharmacol 2004;24:339-42

15. Tanyeri P, Buyukokuroglu ME, Mutlu O, Ulak G, Yıldız Akar F, Komsuoglu Celikyurt I, Erden BF (imip) Involvement of serotonin receptor subtypes in the antidepressant-like effect of beta receptor agonist Amibegron (SR 58611A) an experimental study.Pharmacol Biochem Behav 2013 Apr;105:12-6.

16. Tanyeri P, Buyukokuroglu ME, Mutlu O, Ulak G, Akar FY, Celikyurt IK, Erden BF.Evidence that the anxiolytic-like effects of the beta3 receptor agonist amibegron involve se rotoninergic receptor activity. Pharmacol Biochem Behav 2013 Sep;110:27-32

17. Saitoh A, Kimura Y, Suzuki T, Kawai K, Nagase H, Kamei (desip) Potential anxiolytic and antidepressant-like activities of SNC80, a selective delta-opioid agonist, in behaviora models in rodents.J Pharmacol Sci 2004 Jul;95(3):374-80.

18. Lu X, Ross B, Sanchez-Alavez M, Zorrilla EP, Bartfai T.Phenotypic analysis of GalR2 knockout mice in anxietyand depression-related behavioral tests. Neuropeptides 2008 Aug;42(4):387-97.

19. Porsolt RD, Bertin A, Jalfre M. Behavioral despair in mice: a primary screening test for antidepressants. Arch Int Pharmacodyn Ther 1977;229:327-336.

20. Porsolt RD, Bertin A, Jalfre M. "Behavioural despair" in rats and mice: strain differences and the effects of imipramine. Eur J Pharmacol 1978;51:291-294.

21. Maj J, Rogóz Z, Skuza G, Sowi ska H. The effect of antidepressant drugs on the locomotor hyperactivity induced by
MK-801, a non-competitive NMDA receptor antagonist. Neuropharmacology. 1992 Jul;31(7):685-91.

22. Stemmelin J, Cohen C, Terranova JP, Lopez-Grancha M, Pichat $P$, Bergis $O$, Decobert $M$, Santucci V, Françon $D$, Alonso R, Stahl SM, Keane P, Avenet P, Scatton B, le Fur G, Griebel G. Stimulation of the beta3-Adrenoceptor as a novel treatment strategy for anxiety and depressive disorders. Neuropsychopharmacology 2008 Feb;33(3):574-87.

23. Louis C, Stemmelin J, Boulay D, Bergis O, Cohen C, Griebe G. Additional evidence for anxiolytic- and antidepressantlike activities of saredutant (SR48968), an antagonist at the neurokinin-2 receptor in various rodent-models. Pharmacol Biochem Behav 2008 Mar;89(1):36-45.

24. Costa AP, Vieira C, Bohner LO, Silva CF, Santos EC, De Lima TC, Lino-de-Oliveira C A proposal for refining the forced swim test in Swiss mice.Prog Neuropsychopharmacol Biol Psychiatry 2013 Aug 1;45:150-5.

25. Asakura W1, Matsumoto K, Ohta H, Watanabe HREM sleep deprivation potentiates the effects of imipramine and desipramine but not that of clomipramine in the forced swimming test.Jpn J Pharmacol 1993 Dec;63(4):455-60.

26. Overstreet DH, Stemmelin J, Griebel G. Confirmation of antidepressant potential of the selective beta3 adrenoceptor agonist amibegron in an animal model of depression.Pharmacol Biochem Behav 2008 Jun;89(4):623-6

27. Overstreet DH, Griebel G. Antidepressant-like effects of the vasopressin V1b receptor antagonist SSR149415 in the Flinders Sensitive Line rat. Pharmacol Biochem Behav 2005 Sep;82(1):223-7.

28. Overstreet DH, Griebel G. Antidepressant-like effects of CRF1 receptor antagonist SSR125543 in an animal model of depression. Eur J Pharmacol 2004 Aug 16;497(1):49-53

29. Ide S, Fujiwara S, Fujiwara M, Sora I, Ikeda K, Minami M, Uh GR, Ishihara K. Antidepressant-like effect of venlafaxine is abolished in $\mu$-opioid receptor-knockout mice.J Pharmaco Sci 2010;114(1):107-10.

30. Kitamura Y, Yagi T, Kitagawa K, Shinomiya K, Kawasaki H, Asanuma M, Gomita Y. Effects of bupropion on the forced swim test and release of dopamine in the nucleus accumbens in ACTH-treated rats. Naunyn Schmiedebergs Arch Pharmacol 2010 Aug;382(2):151-8.

31. Morilak DA, Frazer A. Antidepressants and brain monoaminergic systems: a dimensional approach to understanding their behavioural effects in depression and anxiety disorders. Int J Neuropsychopharmacol. 2004 Jun; 7(2):193-218.

32. Gold PW, Goodwin FK, Chrousos GP. Clinical and biochemical manifestations of depression. Relation to the neurobiology of stress (1) N EnglJ Med 1988;319:348-53.

33. D'Aquila PS, Collu M, Gessa GL, Serra G. The role of dopamine in the mechanism of action of antidepressant drugs. Eur J Pharmacol 2000;405:365-373.

34.Dziedzicka-Wasylewska M, Kolasiewicz W, Rogoz Z, Margas W, Maj J. The role of dopamine D2 receptor in the behavioral effects of imipramine - study with the use of antisense oligonucleotides. J Physiol Pharmacol 2000;51:401-409.

35. D’Aquila PS, Canu S, Sardella M, Spanu C, Serra G, Franconi F.Dopamine is involved in the antidepressant-like effect of allopregnanolone in the forcedswimmingtest in female rats. Behav Pharmacol 2010 Feb;21(1):21-8

36. Yamada J, Sugimoto Y, Yamada S.Involvement of dopami nereceptors in the anti-immobility effects of dopamine reuptake inhibitors in the forced swimming test. Eur J Pharmacol 2004 Nov 19;504(3):207-11

37. Leggio GM, Torrisi SA, Castorina A, Platania CB, Impellizzeri AA, Fidilio A, Caraci F, Bucolo C, Drago F, Salomone S.Dopamine D3 receptor-dependent changes in alpha6 GABAA subunit expression in striatum modulate anxietylike behaviour: Responsiveness and tolerance to diazepam. Eur Neuropsychopharmacol 2014 Nov 15. pii: S0924977X(14)00301-0.

38. Bitran D, Hull EM. Pharmacological analysis of male rat sexual behavior. Neurosci Biobehav Rev 1987; 11: 365 389.

39. Shindel AW, Eisenberg ML, Breyer BN, Sharlip ID, Smith
Sakarya Med]

TANYERi et al. Evaluation of The Effects of Antidepressants On Anxiety and Depression 
JF. Sexual function and depressive symptoms among female North American medical students. J Sex Med. 2011;15:391-399.

40. Laurent SM, Simons AD. Sexual dysfunction in depression and anxiety: Conceptualizing sexual dysfunction as part of an internalizing dimension. Clin Psychol Rev. 2009;29:573-85.

41. Stahl SM, Pradko JF, Haight BR, Modell JG, Rockett CB, Learned-Coughlin S. A Review of the Neuropharmacology of Bupropion, a Dual Norepinephrine and Dopamine Reuptake Inhibitor.Prim Care Companion J Clin Psychiatry. 2004;6(4):159-166.

42. Ashton AK, Rosen RC. Bupropion as an antidote for serotonin reuptake inhibitor-induced sexual dysfunction. J Clin Psychiatry. 1998;59:112-115.

43. Gitlin MJ, Suri R, and Alshuler L. et al. Bupropion sustained release as a treatment of SSRI-induced sexual side effects. J Sex Marital Ther 2002 28:131-138.
44. Kennedy SH, McCann SM, and Masellis M. et al. Combining bupropion SR with venlafaxine, paroxetine, and fluoxetine: a preliminary report on pharmacokinetic, therapeutic, and sexual dysfunction effects. J Clin Psychiatry 2002 63:181186.

45. Labatte LA, Grimes JB, and Hines A. et al. Bupropion tre atment of serotonin reuptake antidepressant-associated sexual dysfunction. Ann Clin Psychiatry 1997 9:241-245.

46. Solvason HB, DeBattista C, and Kendrick E. et al. Bupropion SR in the treatment of SSRI-induced sexual dysfunction [poster]. Presented at the 40th annual meeting of the New Clinical Drug Evaluation Unit Program (NCDEU). May 30 June 2, 2000 Boca Raton, Fla. 